\title{
Effect of Temperature on Antimony Leaching from Polyethylene Terephthalate (PETE) into Bottled Water
}

\author{
Al-Ser A. Al-Khatim, Mohamed H. Shiboob and Mohamed F. Elgandy \\ Faculty of Meteorology, Environment and Arid Land Agriculture, King Abdulaziz University, \\ Jeddah, Saudi Arabia \\ akhatim@kau.edu.sa
}

\begin{abstract}
In this research, the level of the heavy metal antimony ( $\mathrm{Sb}$ ) was assessed in seven PETE-bottled water brands, representing major producing firms in Jeddah city. On the same day samples brought from local superstores, each sample underwent 4-replicate analysis (as time-zero $\mathrm{Sb}$ level). Soon after analysis, bottles of each brand were tightly closed, divided into three subsets, stored for 2 months $\left(23^{\circ} \mathrm{C}, 5^{\circ} \mathrm{C}, 50^{\circ} \mathrm{C}\right.$, respectively), then re-analyzed. ICP-OES was used for analysis. $\mathrm{Sb}$ ranged from 0.100 (time-zero) to 1.664- $\mu \mathrm{g} \mathrm{1-1.} \mathrm{Compared} \mathrm{with} \mathrm{time-zero} \mathrm{level,}$ significant $(\mathrm{p} \leq 0.05)$ effects of temperature on $\mathrm{Sb}$ level were observed. Reactivity to elevated temperature indicated a significant variation between some brands at $50^{\circ} \mathrm{C}$. Although the outcomes of this study indicate that $\mathrm{Sb}$ levels increase with elevated temperature, such levels are well below the international MCLs, and are unlikely to exceed them under the standard storage conditions.
\end{abstract}

Keywords. Antimony; Leachability, PETE-Bottled Drinking Water, Brands, Temperature, Contamination.

\section{Introduction}

Contamination of the environment with heavy metals has become a great concern due to the serious effects it poses on human health. Some heavy metals, such as lead $(\mathrm{Pb})$, cadmium $(\mathrm{Cd})$, tin ( $\mathrm{Sn})$, antimony (Sb), etc., are still being used as thermal or UV stabilizers, fillers, flame retardants, colorants, or catalysts in plastics' industry, in the form of their organometallic or inorganic compounds (Hahladakis et al., 2017). Toxic organic and inorganic additives were found to leach from packaging plastics, under various conditions (Guart et al., 2011; Isama et al., 2011). These leachables may include heavy metals, bisphenol A (BPA) and other alkyl phenols, such as 4-nonylphenol, as well as adipates, and phthalates (Muhamad et al., 2011; Keresztes, et al., 2013; Bach et al., 2013; Santana et al. 2014). Many of these agents pose health risks to humans (Halden, 2010), and some have been proved to be xenoestrogens or endocrine disruptors (Kawamura, 2010; Sax, 2010; North and Halden, 2013; Wagner et al., 2013).

In the form of its trioxide or triacetate, $\mathrm{Sb}$ is used worldwide as an initiator or catalyst in PETE manufacturing (Shotyk and Krachler, 2007; Takahashi et al., 2008). Germanium oxide and titanium compounds are also used for this purpose, but $\mathrm{Sb}$ has become the catalyst of choice because it produces a bright and shiny polymer (Haldimann et al. 2013). PETE has become a ubiquitous plastic, being used extensively to fabricate clear and transparent plastic containers (colored and uncolored) to package drinking water, 
beverages, various food products and pharmaceuticals. A number of researchers have proved that PETE is not an exception, with regard to the chemical migration phenomenon known in plastics. Several scientists (Greifenstein et al., 2013; SánchezMartínez et al., 2013; Welle and Franz, 2011) confirmed contamination of PETE-packaged foodstuffs and soft drinks with leaching Sb.

Hoppe et al. (2017) confirmed the leachability of oligomers from PETE that, according to their findings, have originated from the polymeric material. Phthalate esters, used as plasticizers, where found by Keresztes et al. (2013) to migrate from PETE containers into packaged water.

Bottled water has grown to a multimillion dollar industry worldwide. Saudi Arabia ranks 13 among the 71 countries reported to have a high per capita consumption of bottled water (Al-Saleh, et al., 2011), with PETE being used predominantly to package and market this type of drinking water. Boosted by the rapid increase in population and hot weather, the demand for bottled water in the Saudi Arabian market has risen remarkably and is expected to rise even more in the next few years. The fact that tap water is still widely perceived as impure and unhealthy for drinking, is a major factor behind consumers' growing preference for bottled water (Al-Sulaiman, 2015).

The present work focuses the levels of contamination with $\mathrm{Sb}$ in locally PETE-bottled water, the effects of temperature on these levels, and whether these levels are in compliance with the international guideline limits set for the MCLs of this heavy metal in this type of drinking water.

\section{Material and Analytical Method}

PETE-based bottled drinking water was used in this study. Seven fresh samples, representing major bottled-water brands, widely marketed in the vast residential area of Jeddah city, as well as its outskirts, were selected randomly under similar conditions, on the same day, from major superstores. Production date of these brands was almost the same, and each brand's expiry date was set at one year. The water bottles were of similar shape and volume $(0.251)$. The plastic material was identified as PETE by the global resin identification number seen inside the recycling triangle on the bottom surface of each bottle. Collectively, a total of 21 water bottles were used in this study.

The $\mathrm{Sb}$ content was determined, within 2-6 $\mathrm{h}$ of samples' purchase, according to the following protocol: on the day samples were procured, analysis of all brands for $\mathrm{Sb}$ was performed and regarded as time-zero concentration. The same three bottles for each of the seven brands, used for time-zero analysis, were subjected to three different treatment conditions, starting from the same day of time-zero analysis, dividing each the 3 brand bottles into three subsets, one bottle each. The bottles were sealed and stored; one bottle under room temperature $\left(23^{\circ} \mathrm{C}\right)$, the other at $5^{\circ} \mathrm{C}$ (in the fridge) and the third at $50^{\circ} \mathrm{C}$ (in the incubator). Bottles under these treatment conditions continued for two months. Any sort of contamination or damage during the experiment and analytical procedure was strictly avoided.

Deionized water (Millipore, Molsheim, France) was used to prepare dilute concentrated nitric acid (37\%; $\mathrm{BDH}$ Chemicals Ltd.), calibration blanks and $\mathrm{Sb}$ standards from the stock solution (Inorganic Ventures Company, USA). Concentrated nitric acid was added (by 2\%) to the blanks and samples and allowed to equilibrate at room temperature for $2 \mathrm{hrs}$. Reagents used were of analytical grade. Glassware (volumetric and conical flasks, pipettes) used were treated by 
dilute (1:1) nitric acid and then rinsed with deionized water before use.

Following well hand shaking to homogenize each sample, measurement of total soluble $\mathrm{Sb}$ was conducted using Inductively Coupled Plasma-Optical Emission Spectrometer (ICP-OES) -Varian Inc., USA. Four replicates of $10-\mathrm{mL}$ aliquot from blanks and each brand were sampled for each $\mathrm{Sb}$ analysis.

\section{Statistical Analysis}

Two-way analysis of variance (ANOVA) was used to test the data obtained for the seven brands stored under each treatment condition, in comparison with timezero $\mathrm{Sb}$ level. A general linear model (GLM) procedure was applied, using Proc GLM of SAS v.9.2 (SAS Institute Inc., 2008).

\section{Results and Discussion}

Table 1 presents the outcomes of analyzed data generated from $\mathrm{Sb}$ analysis of the samples. The mean level (of four replicates) of each brand bottled-water under each treatment condition is shown, as well as the means for the seven brands together, under each treatment condition, including time-zero level. Comparison between mean values within the same treatment condition showed no significant difference between the brands under conditions of $23^{\circ} \mathrm{C}$ and $5^{\circ} \mathrm{C}$. Brands' time-zero mean values were almost the same. However, these mean values showed a significant difference among these brands under $50^{\circ} \mathrm{C}$ (as could be deduced from superscripts). That is, the first three brands (1$3)$ are significantly different $(p \leq 0.05)$ from the others (4-7). Figure 1 expresses the reactivity of these brands, toward each of the applied treatment conditions, in terms of $\mathrm{Sb}$ levels produced by leachability of PETE.

A significant difference $(\mathrm{p} \leq 0.05)$ among the $\mathrm{Sb}$ mean values under the four treatment conditions is clearly observed in Table 1. The $\mathrm{Sb}$ mean values followed the order: time-zero $<$ fridge $<$ room temperature $<$ incubator, in the range: $0.100-1.664 \mu \mathrm{g} \mathrm{l}^{-1}$. Figure 2 provides a clear picture of the mean $\mathrm{Sb}$ levels under these treatment conditions.

Table 1. Mean antimony (Sb) concentrations $\left(\mu \mathrm{g} \mathrm{l}^{-1}\right)$ in PET-bottled drinking water stored at three different temperatures, compared with initial

\begin{tabular}{|c|c|c|c|c|}
\hline Brand No. & $\begin{array}{c}\text { Initial at room temp. } \\
\left(23^{\circ} \mathrm{C}\right)\end{array}$ & After 2 months $\left(23^{\circ} \mathrm{C}\right)$ & $\begin{array}{c}\text { After 2 months in fridge } \\
\left(5^{\circ} \mathrm{C}\right)\end{array}$ & $\begin{array}{c}\text { After 2 months in incubater } \\
\left(50^{\circ} \mathrm{C}\right)\end{array}$ \\
\hline 1 & $0.110^{\mathrm{hi}}$ & $0.739^{\text {cdefg }}$ & $0.425^{\text {dgefhi }}$ & $2.495^{\mathrm{a}}$ \\
\hline 2 & $0.270^{\text {ghhi }}$ & $1.001^{\text {bcd }}$ & $0.4610^{\text {dgefhi }}$ & $2.061^{\mathrm{a}}$ \\
\hline 3 & $0.199^{\text {ghi }}$ & $0.914^{\text {bcde }}$ & $0.380^{\text {gefhi }}$ & $1.124^{\mathrm{a}}$ \\
\hline 4 & $0.067^{\mathrm{i}}$ & $1.101^{\text {bc }}$ & $0.424^{\text {dgefhi }}$ & $0.9388^{\text {bcde }}$ \\
\hline 5 & $0.0923^{\text {hi }}$ & $0.8830^{\text {bcde }}$ & $0.500^{\text {dgefhi }}$ & $0.9555^{\text {bcde }}$ \\
\hline 6 & $0.1035^{\text {hi }}$ & $0.8200^{\text {bcdef }}$ & $0.5920^{\text {cdefghi }}$ & $1.3708^{\mathrm{b}}$ \\
\hline 7 & $0.1030^{\text {hi }}$ & $0.7118^{\text {cdefg }}$ & $0.6753^{\text {cdefgh }}$ & $1.583^{\mathrm{A}}$ \\
\hline
\end{tabular}

PET polyethylene terephthalate

Each $\mathrm{Sb}$ value in the Table, under these treatments, represents a mean of four replicates

${ }^{\mathrm{a}-\mathrm{c}}$ Means within treatments are significantly different $(p \leq 0.05)$.

A-D Means within applied conditions are significantly different $(p \leq 0.05)$

* Mean of Sb concentration corresponding to each condition. 


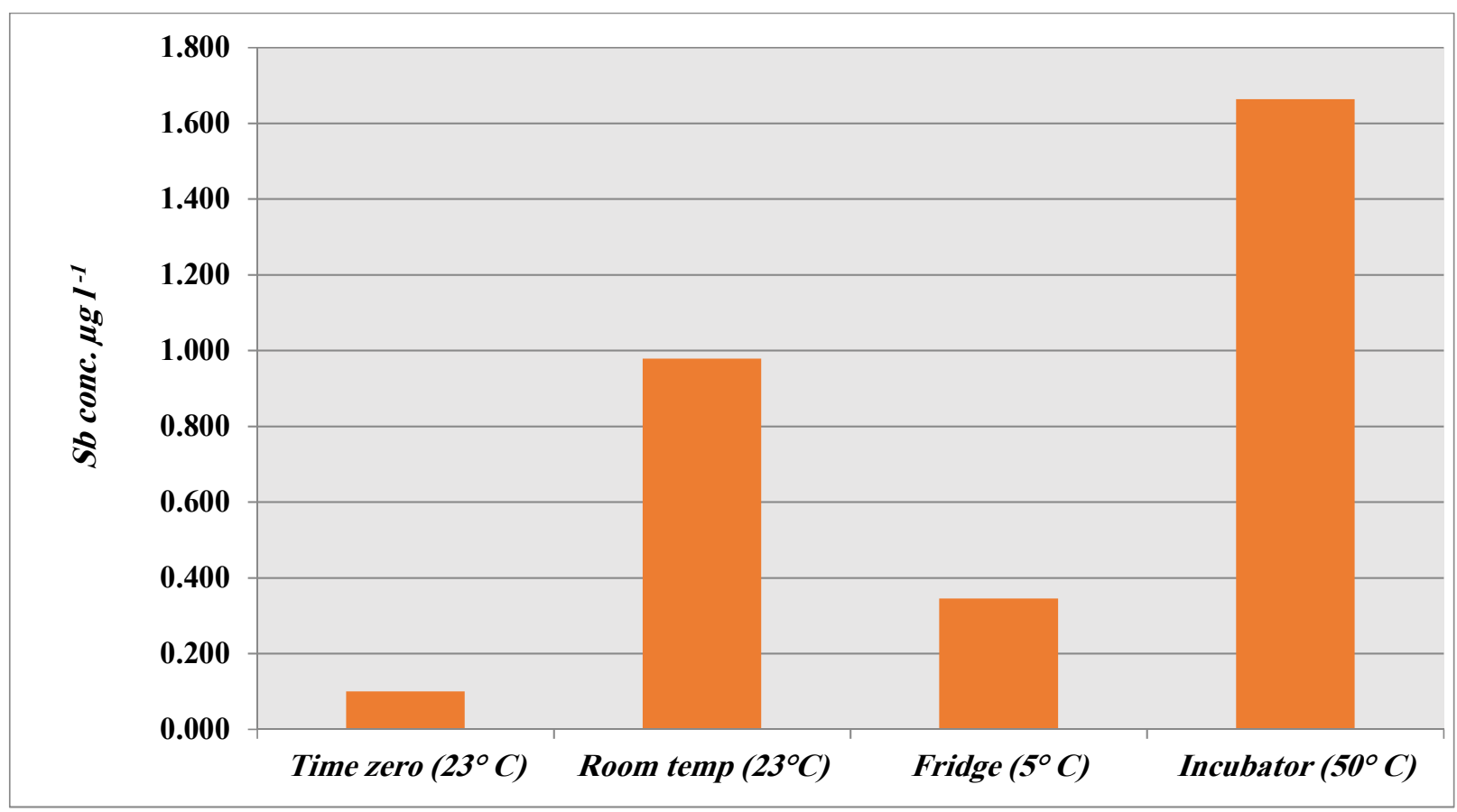

Fig. 1. Mean concentration of antimony $(\mathrm{Sb})\left(\mu \mathrm{g} \mathrm{l}^{-1}\right)$ of PETE-Bottled-water brands, under each experiment condition applied under 2-month storage, compared with time-zero level.

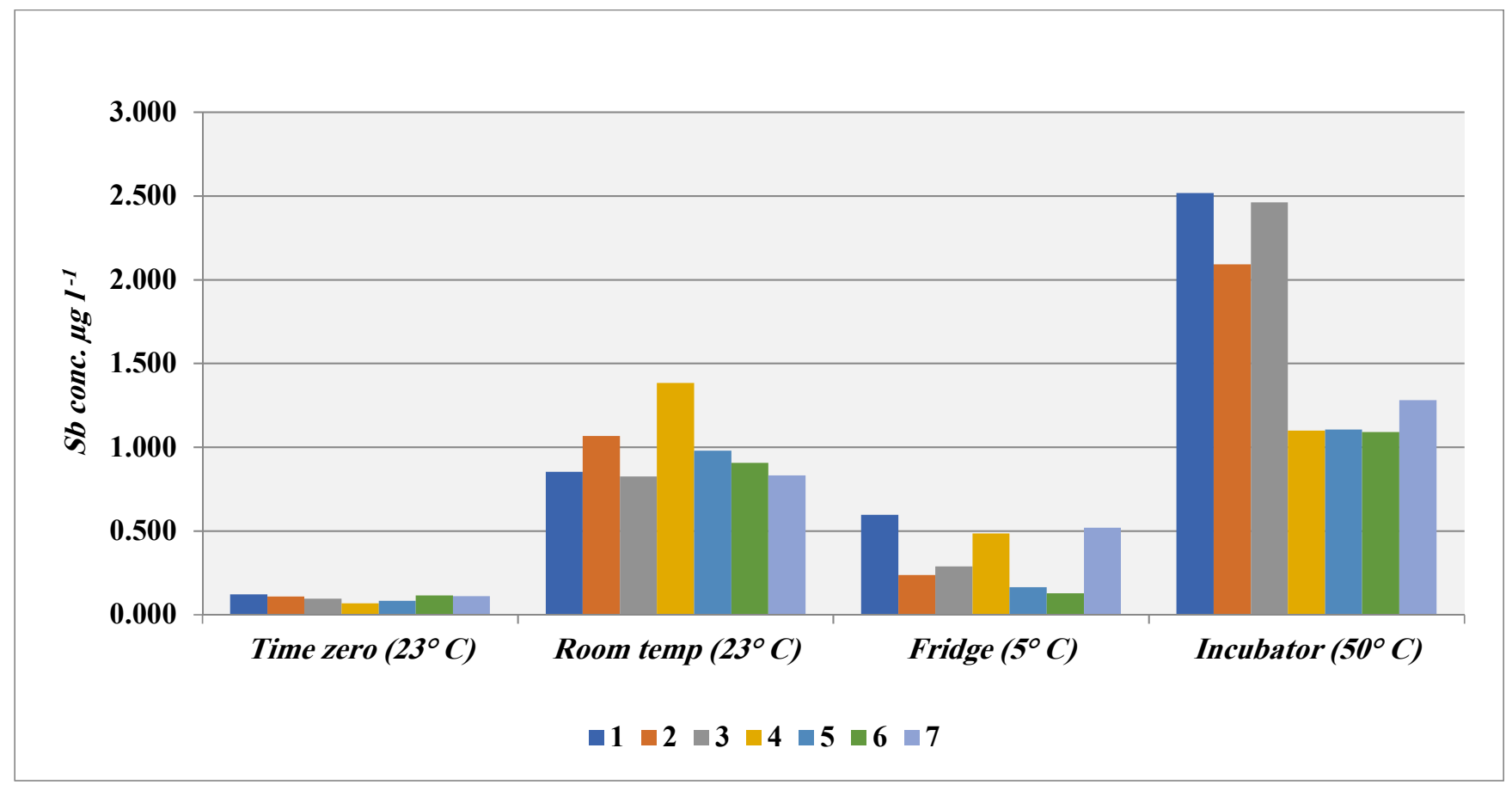

Fig. 2. Variation among seven brands of PETE-bottled-water in response to each experiment condition applied, under 2month storage, expressed as antimony $(\mathrm{Sb})$ mean concentration $\left(\mu \mathrm{g}^{-1}\right)$ for each brand, compared with initial level. 
Commercial providers of bottled drinking water and other drinks have adopted PETE to package their product. This mostly is due to the fact that PETE is considered by many to be a safe packaging polymeric material, which explains the extensive use of PETE in packaging of food products and beverages worldwide. In a previous study by Al-Khatim and Shiboob (2015), a number of local major superstores were surveyed to check the types of plastics used to fabricate the packaging systems used by the diversified food industry. The investigation covered hundreds of different food items, including drinking water and beverages, packaged or stored in the 7 types of plastics used in this regard. Of these types, PETE was found to be the most prevalent type (43\%) at present.

Antimony, as a heavy metal, has been shown to be a leachable contaminant in PETEbottled water and soft drinks (Westerhoff et al., 2008; Andra et al., 2012; Payán et al., 2017). Cheng et al. (2010) indicated that this contamination from PETE comes partially from the surface of bottles as a result of the manufacturing process, while major antimony migrates from beyond the PETE surface, depending on conditional changes. They suggested that all plastic containers should be washed during manufacturing before being filled with drinking water or food products. Based on their finding, it could be inferred that the $\mathrm{Sb}$ content of the water samples studied here has originated from both sources, but the temperature should be accounted for migrating $\mathrm{Sb}$, which mainly have led to the significant $\mathrm{Sb}$ elevation observed in these samples.

According to Cheng et al. (2010), heating and microwaving enhance antimony leaching significantly in PETE plastic bottles. The elevated temperature applied in the present study $\left(50^{\circ} \mathrm{C}\right)$, gave rise to significantly higher Sb level, which supports the finding of Fan et al. (2014), although, in our view, the temperature these scientists applied $\left(70{ }^{\circ} \mathrm{C}\right)$ was extreme and is not applied neither at the time of packaging nor during storage of bottled water. On the other hand, low temperature (in the fridge) is apparently effective in decelerating Sb leachability, but concentrations remain significantly higher than time-zero level. It might be perceived by many that low temperature (fridge) can suppress plastics' leachability, but the present study indicates that $\mathrm{Sb}$ leaching is difficult to curb, even under low temperatures.

It should be noted that the maximum contaminant level (MCL) for $\mathrm{Sb}$ in drinkingwater in Japan is set at $2 \mu \mathrm{g} \mathrm{l}^{-1}$, in EU is at 5 $\mu \mathrm{g} 1^{-1}$, while in USA and Canada it is observed at $6 \mu \mathrm{g} \mathrm{l}^{-1}$ (Andra et al., 2012). These MCLs are set to avoid or reduce the risk of exposure in those who consume this type of water on a regular basis. According to Sundar and Chakravarty (2010), Sb, in its trivalent state, $\mathrm{Sb}$ has been shown to be more toxic than its pentavalent one, due to its high affinity for thiol (-SH) groups of the sulfur-containing amino acids cysteine and cystine that are involved in the structure of various proteinaceous biological molecules. Due to such affinity, enzyme inhibition can result, leading to impaired cellular enzymes, in particular those involved in cellular respiration and carbohydrate or protein metabolism (Beyersmann and Hartwig 2008). The outcomes reported by Poon et al. (1998) manifested a number of histological and biochemical changes due to $\mathrm{Sb}$ induced toxicity. Although the $\mathrm{Sb}$ levels detected in the PETE-bottled water under the present study were well below the above guideline values, these levels can rise with temperature to higher levels, as indicated by these scientists.

The variation observed among some of these brands, with regard to reactivity or response of the packaging material to the 
conditions applied, might be attributed to a nonstandard process or to the quality of PETE raw material used for the production of the pre-form, i.e., virgin vs. polymer containing recycled PETE (Keresztes et al., 2013).

\section{Conclusion}

The antimony $(\mathrm{Sb})$ levels revealed by the present study are well below the international standards. Based on these findings, it could be indicated that PET-bottled drinking water, investigated here, must be safe for the human consumption, with regard to leachability of PET for this element. Even at elevated temperatures, as of $50^{\circ} \mathrm{C}$ or less, $\mathrm{Sb}$ is not expected to exceed the international MCL set for this heavy metal.

\section{References}

Al-Khatim, A.A. and Shiboob, M.H. (2015). Verifying the prevalence of PET plastic in food packaging. J. of King $A$. Aziz University: Met. Env. Arid Land Agric., 26(1): 37-43.

Al-Saleh, I., Shinwari, N. and Alsabbaheen, A. (2011). Phthalates residues in plastic bottled waters. $J$ Toxicol Sci., 36(4): 469-78.

Al-Sulaiman, M.A. (2015). Study on physicochemical properties of domestic bottled drinking water brands in Saudi Arabia, Indian J. Appl. Research, 5(3): 168-171.

Andra, S.S., Makrisa, K.C., Shineb, J.P. and Lub, C. (2012). Co-leaching of brominated compounds and $\mathrm{Sb}$ from bottled water, Environment International, 38(1): 4553.

Bach, C., Dauch, X., Severin, I., Munoz, J.F., Etienne, S. and Chagnon, M.C. (2013). Effect of temperature on the release of intentionally and non-intentionally added substances from polyethylene terephthalate (PETE) bottles into water: chemical analysis and potential toxicity, Food Chem., 139(1-4): 672-80.

Beyersmann, D. and Hartwig A. (2008). Carcinogenic metal compounds: recent insight into molecular and cellular mechanisms, Arch. Toxicol., 82: 493-512.

Cheng, X., Shi, H., Adams, C.D. and Ma, Y. (2010). Assessment of metal contaminations leaching out from recycling plastic bottles upon treatments, Environ. Sci. Pollut. Res. Int., 17(7): 1323-30.

Fan, Y.Y., Zheng, J.L., Ren, J.H., Luo, J., Cui, X.Y. and Ma, L.Q. (2014). Effects of storage temperature and duration on release of antimony and bisphenol A from polyethylene terephthalate botteled drinking water of China. Environ. Pollution, 192: 113-120.
Greifenstein, M., White, D.W., Stubner, A., Hout, J. and Whelton, A.J. (2013). Impact of temperature and storage duration on the chemical and odor quality of military packaged water in polyethylene terephthalate bottles. Sci. Total Environ, 456-457C: 376-83.

Guart, A., Bono-Blay, F., Borrell, A. and Lacorte, S. (2011). Migration of plasticizers phthalates, bisphenol A and alkylphenols from plastic containers and evaluation of risk, Food Chem., 28(5): 676-85.

Hahladakis, J.N.I., Velis, C.A., Weber, R., Iacovidou, E. and Purnell, P. (2017). An overview of chemical additives present in plastics: Migration, release, fate and environmental impact during their use, disposal and recycling, J. Hazard Mater., 344:179-199.

Halden, R.U. (2010). Plastics and Health Risks. Annual Review of Public Health. 31, 179-194.

Haldimann, M., Alt, A., Blanc, A., Brunner, K., Sager, F. and Dudler, V. (2013). Migration of antimony from PETE trays into food simulant and food: determination of Arrhenius parameters and comparison of predicted and measured migration data, Food Addit. Contam. Part A, 30(3): 587-98.

Hoppe, M., Fornari, R., de Voogt, P. and Franz, R. (2017). Migration of oligomers from PET: determination of diffusion coefficients and comparison of experimental versus modelled migration, Food Addit Contam Part A Chem Anal Control Expo Risk Assess, 34(7):1251-1260.

Isama, K.1., Kawakami, T. and Nishimura, T. (2011). Migration of eight harmful elements from household products made with synthetic resin that infants may swallow by mistake. Yakugaku Zasshi: Journal of the Pharmaceutical Society of Japan, 131(7): 1135-40.

Kawamura, M. (2010). Endocrine disruptors in food contact articles and baby toys with their transition, Bulletin of National Institute of Health Sciences, 128: 17-26.

Keresztes, S., Tatár, E., Czégény, Z,. Záray, G. and Mihucz, V.G. (2013). Study on the leaching of phthalates from polyethylene terephthalate bottles into mineral water. Sci. Total Environ, 458-460: 451-458.

Muhamad, S.G., Esmail, L.S. and Hasan, S.H. (2011). Effect of storage temperature and sunlight exposure on the physicochemical properties of bottled water in Kurdistan region-Iraq, Journal of Applied Sciences and Environmental Management, 15 (1): 127-133.

North, E.J. and Halden, R.U. (2013). Plastics and environmental health: the road ahead, Rev. Environ. Health, 28(1): 1-8.

Payán, L., Poyatos, M.T., Muñoz, L., La Rubia, M.D., Pacheco, R. and Ramos, N. (2017). Study of the influence of storage conditions on the quality and migration levels of antimony in polyethylene terephthalate-bottled water, Food Sci. Technol. Int., 23(4): 318-327.

Poon, R., Chu, I., Lecavalier, P., Valli, V.E., Foster, W., Gupta, S. and Thomas, B. (1998). Effects of 
antimony on rats following 90-day exposure via drinking water, Food and Chemical Toxicology, 36(1): 21-35.

Sánchez-Martínez, M., Pérez-Corona, T., Cámara, C. and Madrid, Y. (2013). Migration of antimony from PETE containers into regulated EU food simulants. Food Chem.,141(2): 816-22

Santana, J., Giraudi, C., Marengo, E., Robotti, E., Pires, S., Nunes, I. and Gaspar, E.M. (2014). Preliminary toxicological assessment of phthalate esters from drinking water consumed in Portugal, Environ Sci. Pollut. Res. Int., 21(2): 1380-90.

SAS (2008). Statistical Analysis System User's Guide (2nd Ed) (Version 9.2). SAS Institute Inc., Cary, North Carolina, USA.

Sax, L. (2010). Polyethylene terephthalate may yield endocrine disruptors. Environ Health Perspec, 118(4): 445-8.

Shotyk, W. and Krachler, M. (2007). Contamination of bottled waters with Sb leaching from polyethylene terephthalate PETE) increases upon storage, Environ. Sci. Technol., 41(5): 1560-3.
Sundar, S. and Chakravarty, J. (2010). Antimony toxicity. Int. J. Environ. Res. Public Health, 7(12): 4267-4277.

Takahashi, Y., Sakuma, K., Itai, T. , Zheng, G. and Mitsunobu S. (2008). Speciation of antimony in PET bottles produced in Japan and China by X-ray absorption fine structure spectroscopy, Environ Sci. Technol., 42(24): 9045-50.

Wagner, M., Schlüsener, M.P., Ternes, T.A. and Oehlmann, J. (2013). Identification of Putative Steroid Receptor Antagonists in Bottled Water: Combining Bioassays and High-Resolution Mass Spectrometry, PLoS ONE., 8(8): e72472.

Welle, F. and Franz, R. (2011). Migration of antimony from PET bottles into beverages: determination of the activation energy of diffusion and migration modelling compared with literature data, Food Addit. Contam. Part A., 28(1): 115-26.

Westerhoff, P., Prapaipong, P., Shock, E. and Hillaireau, A. (2008). Antimony leaching from polyethylene terephthalate (PETE) plastic used for bottled drinking water, Water Res., 42: 551-556. 
تأثثر درجة الحرارة على ارتشاح عنصر الأنتمون من البولي إيثلين إلى مباه الثرب المعبأة

\title{
السر علي الختم، و محمد حمد شيبوب، و محمد فتحي الجندي
}

كلية الأرصاد والبيئة وزراعة المناطق الجافة، جامعة الدلك عبد العزيز، جدة، المدلكة العربية السعودية akhatim@kau.edu.sa

\begin{abstract}
المستخلص. تم تقييم مستوى عنصر الأنتمون في مياه V شركات مياه شرب رئيسة بمدينة

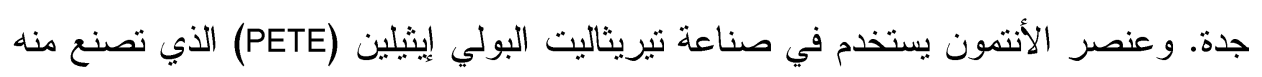

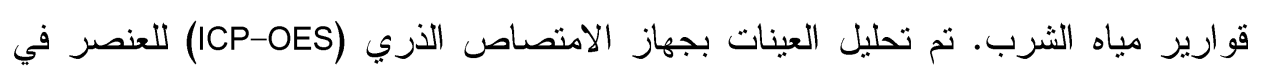

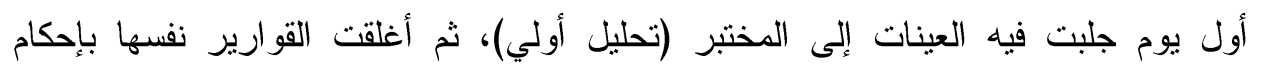

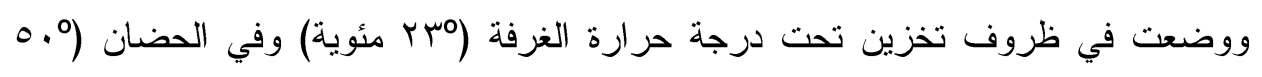

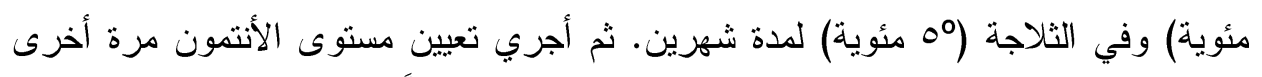
في نهاية المدة. أجري التحليل في المرتين بأربعة تكرارات. بئَّ التحليل الإحصائي للبيانات

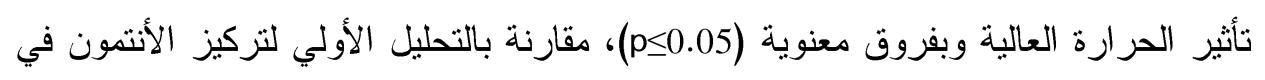

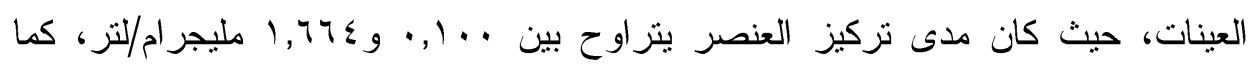

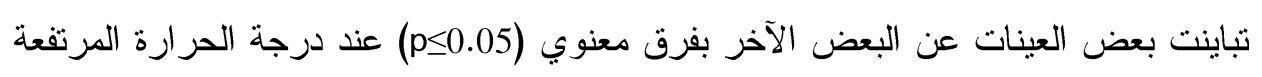

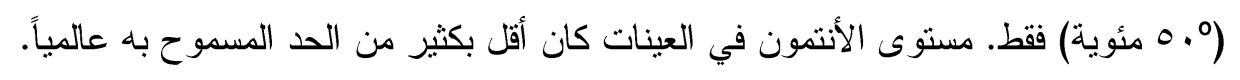
الكلمات الدفتاحبة: عنصر الأنتمون، ارتشاح، مياه الثرب المعبــأة، قوارير PETE، شركات مياه، درجة حر ارة، تلوث.
\end{abstract}

